\title{
Bibliodrama kao pastoralni izazov
}

\author{
ZDRAVKA LEUTAR* \\ • https://doi.org/10.31823/d.27.3.8 • \\ UDK: 27-23-46 • Pregledni članak \\ Primljeno: 7. studenoga 2018. • Prihvaćeno: 9. rujna 2019.
}

Sažetak: U uvodnom dijelu rada donosi se povijesni prikaz nastanka bibliodrame. Bibliodrama je metoda grupnoga pristupa biblijskomu tekstu u kojoj se sudionici koriste dramskom kreativnom tehnikom i spontanošću radi individualnoga osvješćivanja $i$ osnaživanja, izgradnje što kvalitetnijih interpersonalnih odnosa i zajedništva s Bogom i jednih s drugima. Ne postoji nijedna životna situacija za koju se u Bibliji ne bi moglo pronaći odgovarajuće životno iskustvo. Sudionici bibliodrame unose svoje životno iskustvo u biblijski tekst i produbljuju ga, duboko integrirajući vlastiti život i osvješćujući vlastitu stvarnost, te time postaju osnaženi. U radu se teoretski analiziraju različiti pristupi bibliodrami, osobito europski i američki. Nadalje se obraduje sedam tipova bibliodrame i njihovi predstavnici. Bibliodrama se u Hrvatskoj u pastoralnom radu i u

* Prof. dr. sc.

Zdravka Leutar,

Pravni fakultet

Sveučilišta u Zagrebu, Studijski centar socijalnog rada, Nazorova 51, 10000 Zagreb, Hrvatska, zdravka.leutar@pravo.hr pomažućim profesijama primjenjuje od 2013. godine. U Hrvatsku je bibliodrama donesena iz Njemačke i to je vrsta bibliodrame proizišle iz psihodrame. Njezina struktura jest kako slijedi: Upoznavanje i zagrijavanje; Rad na životnoj strani; Rad s biblijskim tekstom; Rad na životnoj strani s pomoću uloga iz biblijskoga teksta; Integracija. U radu se analiziraju elementi navedene strukture s pomoću prikaza aktivnosti jedne sudionice u bibliodrami i pojašnjenja pojedinih elemenata. Vrlo je važno da voditelj bibliodrame poznaje psihodinamiku grupe koja može uvelike pomoći boljoj izvedbi bibliodrame, a može proizvesti $i$ otpore $i$ regresiju sudionika. Bibliodrama se u pastoralnom radu primjenjuje na svim dobnim skupinama, no najčešće se primjenjuje u grupama s mladima i djecom. Bibliodrama se može primjenjivati i u različitim skupinama unutar župne zajednice u smislu postizanja što kvalitetnije grupne kohezije i zajedništva. Moguće ju je primjenjivati i pri osnaživanju pastoralnih djelatnika i pri radu na sebi. Bitna di- 
menzija bibliodrame jest ta da uključuje cjelovitoga čovjeka na svim četirima razinama: kognitivnoj, emocionalnoj, duhovnoj i socijalnoj.

Ključne riječi: bibliodrama, pastoralni rad, rad na sebi, interpersonalni odnosi, zajedništvo.

\section{Uvod}

Bibliodrama je interpersonalan pristup biblijskomu tekstu. Ideja bibliodrame nastala je iz psihodrame J. R. Morena iz 1921. godine, ${ }^{1}$ no s intenzivnijim kreiranjem psihodrame započelo se kasnije, kada 1950. godine Moreno napušta Beč i u Americi sastavlja skalu aktivnosti. Bilo je to vrijeme davanja pozornosti terapijskim edukacijskim učincima i drami te je u okviru toga Morenova psihodrama bila razmatrana kao dobro polazište za grupne terapijske aktivnosti. Neki su se kršćani upoznali $s$ tim ozračjem, pa su dramske metode postale začetnici područja nazvanoga bibliodrama. »Često me pitaju što smatram svojim najvećim znanstvenim doprinosom. Po mom mišljenju, to nije ni psihodrama ni grupna psihoterapija, već sociometrija, znanost interpersonalnoga mjerenja. Ona je dala čvrste temelje za grupnu psihoterapiju. Sociometrija je djelo mnogih istraživača i prihvaćena je s nešto otpora prema grupnoj psihoterapiji i psihodrami. Ima oblik egzaktne znanosti. Činjenica da sam počeo sa sociometrijom često se previđa zbog globalne popularnosti koju su postigle grupna psihoterapija i psihodrama. $\ll^{2}$

Prošlo je više od trideset godina otkako je bibliodrama nastala u evangeličkim područjima Njemačke. Na samom početku 80 -ih godina prošloga stoljeća muškarci i žene identificirali su se s pojedinim ulogama izmjenjujući biblijski tekst i scenski prikaz. Uprizorenje različitih inačica pomaže sudionicima u procesu unošenja vlastitoga iskustva u kontekst biblijskoga teksta. Tako bibliodrama, imajući interdisciplinaran pristup, prerasta u pokret koji je uključivao i egezegetske i psihološke i pedagoške i estetske spoznaje, stoga ne dodirujući isključivo teologiju, nego i područja psihologije, pedagogije, socijalnoga rada i drame. Pokret se vrlo brzo proširio, pa je 1994. godine utemeljeno Njemačko društvo za bibliodramu. Kao

\footnotetext{
${ }^{1}$ MORENO, Jacob Levy (1892. - 1974.), američki psihijatar rumunjskoga podrijetla. Rođen u Bukureštu 20. svibnja 1892., Jakov Levy Moreno utemeljio je sociometriju, grupnu psihoterapiju i psihodramu - oblik grupne terapije koju je sam opisao kao »traganje za istinom pomoću dramskih metoda «. Objavljivao je i istoimeni časopis Psychodrama. Moreno je živio u Beču prije nego što će 1925. godine emigrirati u Sjedinjene Američke Države. Od 1951. godine bio je profesor na sveučilištu u New Yorku. Umro je 14. svibnja 1974. godine u Beaconu, New York. Podrijetlo bibliodrame također se povezuje s Morenom.

${ }^{2}$ Usp. J. L. MORENO, Gruppenpsychotherapie und Psychodrama. Einleitung in die Theorie und Praxis, Stuttgart - New York, 2008., 46-47.
} 
ekumenska metoda rada s Biblijom koristi se u različitim kršćanskim zajednicama, a kasnije i interkonfesionalno, i u drugim zemljama i kulturama te je 2004. godine utemeljeno Europsko društvo za bibliodramu koje obuhvaća: Njemačku, Austriju, Švicarsku, Mađarsku, Dansku, Švedsku, Finsku, Litvu, Norvešku, Englesku, Češku, Koreju, Poljsku, Italiju i Kanadu. ${ }^{3}$ Paralelno s razvojem bibliodrame u Njemačkoj Peter Pitzele, američki psihodramatičar, 1984. godine započeo je s vlastitom bibliodramom u SAD-u bez da se prethodno upoznao s europskom bibliodramom. ${ }^{4}$ Pitzele je bio tražen da podučava na Židovskom teološkom sjemeništu u New Yorku. Koristeći se svojim psihodramskim vještinama, Pitzele je od studenata zatražio da se opišu kao da bi bili Mojsije i odgovore na pitanja iz Mojsijeve perspektive. Studenti su prepoznali tu tehniku i ona im je pomogla da razumiju Mojsija na nov način i ujedno rasvijetle svoje osobne nutarnje sukobe i tjeskobe. ${ }^{5}$ Pitzele je tako otpočeo držanje seminara o podučavanju te biblijske metode igranja uloga po sinagogama, crkvama, učionicama, pastoralnim centrima i terapeutskim zajednicama. Njegova se metoda naziva bibliolog. Posljedično tomu bibliodrama se u Sjevernoj Americi i Izraelu većinom proširila upravo sukladno strukturi koju je on promovirao. Muchlinsky ${ }^{6}$ tvrdi da se bibliologom ili Pitzeleovim oblikom bibliodrame koristi za veće skupine, primjerice cijele zajednice. Pitzele ${ }^{7}$ izvještava da je vodio bibliolog i s vrlo velikim skupinama, od 300 do 500 sudionika. Pitzele ${ }^{8}$ predstavlja svoju bibliodramu kao metodu susreta s Biblijom radi obrazovanja, izgradnje zajednice i osobnoga ozdravljenja. Europska bibliodrama provodi se s manjim grupama. Gerhard Marcel Martin, jedan od inicijatora europske bibliodrame 1970-ih, preporučuje da se bibliodramske skupine sastoje od dvanaest do osamnaest sudionika. ${ }^{9}$ S bibliodramom se u Hrvatskoj započelo 2013. godine u okviru redovničke zajednice Klanjateljica Krvi Kristove, odnosno jednoga od projekata Zaklade »Marija De Mattias «. Skupina sudionica u razdoblju od 2011. do 2013. godine pohađala je dvogodišnju edukaciju koju je vodio Helmut Kreller iz Erlangena, Njemačka. Tu prvu skupinu educiranih voditeljica bibliodrame čini devet sestara Klanjateljica

\footnotetext{
${ }^{3}$ Usp. M. E. AIGNER, Bibliodrama und Bibliolog als pastorale Lernorte, Stuttgart, 2015.

${ }^{4}$ Usp. P. PITZELE, Bibliodrama: A prophetical advertisement, u: The Reconstructionist 62(1997.)1, 57-64.

${ }^{5}$ Usp. P. PITZELE, Scripture windows: Toward a practice of bibliodrama, Los Angeles, 1998.

${ }^{6}$ Usp. F. MUCHLINSKY, The Bible is alive - bibliolog, 2013. Dostupno na: http://www.muchlinsky. de/bibliolog.html (27.7. 2017.)

${ }^{7}$ Usp. P. PITZELE, Bibliodrama: A call to the future, 2008. Dostupno na: http://www.bibliodrama. com/bibliodrama-a-call-to-the-future/ (11.10.2019.)

${ }^{8}$ Usp. P. PITZELE, Scripture windows: Toward a practice of bibliodrama, Los Angeles, CA, 1998.

${ }^{9}$ Usp. G. MARTIN, The origins of bibliodrama and its specific interest in the text, citirano prema: $B$. KRONDORFER, Body and Bible, Philadelphia, PA, 1992., 85-101.
} 
Krvi Kristove, dvije socijalne radnice i jedna profesorica njemačkoga jezika. To je zasad i jedina takva grupa u Hrvatskoj. Hrvatska još uvijek nema Hrvatsko društvo za bibliodramu i u Hrvatskoj još uvijek nije moguće pohađati tu vrstu edukacije jer nemamo licencirane trenere za bibliodramu. ${ }^{10}$

\section{Spontana i kreativna grupna metoda rada s biblijskim tekstom}

Pojam bibliodrama sastavljen je od dviju grčkih riječi - biblion, što znači 'knjiga' i drama, što znači 'djelovanje, učinak'. Ovdje, zapravo, subjekt uključen u bibliodramu dolazi sa svojim sadašnjim životom i stvarnošću i to povezuje s biblijskim tekstom te zatim taj biblijski tekst ponovno povezuje sa svojom stvarnošću subjekta (život - Biblija - život). Bibliodrama je životna interpretacija biblijskoga teksta u emocionalnoj, kognitivnoj i duhovnoj nazočnosti sudionika. ${ }^{11}$ Zajedništvo i disonancije u sebi nose životne impulse. Bibliodrama je kreativan i spontan proces. Svakomu je čovjeku koji je rođen $\gg \mathrm{zdrav} \ll{ }^{12}$ dana mogućnost kreativnosti i spontanosti. Kreativnost je pri tome dio Božje kreativne snage u čovjeku. Kao što je Bog stvorio čovjeka i svijet, tako čovjek može biti njegov sustvaratelj is Bogom izgrađivati novi svijet. Spontanost čovjeku omogućava da stvara novo jer je izbjegavanjem uvijek istoga načina moguće ostvariti kreativno ljudsko djelovanje i u svakome ga trenutku učiniti jedinstvenim, bez da je ranije bilo planirano ili predviđeno. To je izravan proces. ${ }^{13}$ Taj kreativan i spontan proces treba u bibliodrami stare, dobro poznate biblijske tekstove probuditi i učiniti plodonosnima za bolji život i bolji svijet. Bibliodrama je jedno novo doživljavanje, jedan nov stav. Biblijski tekst možemo pročitati i ne zamijetiti puninu njegova sadržaja. No u bibliodrami u njega ulazimo polagano i postupno i s velikom pozornošću promatramo sadržaj svake riječi, rečenice i cjelokupnoga teksta. Pri tome mnogo dublje ulazimo u sam tekst i on obuzima sudionike na kognitivnoj i emocionalnoj razini. Na taj način sudionik može mnogo dublje zamijetiti smisao i svu ljepotu biblijskoga teksta. ${ }^{14}$

Biblija je prožeta odnosima čovjeka s drugim ljudima, njegovim osobnim stanjima, traženjem identiteta te oslikava čovjekovu društvenu stvarnost. Bibliodrama u središte stavlja samoga čovjeka, pomaže mu da bolje upozna samoga sebe, da se poistovjeti s nekim od biblijskih likova kako bi na taj način lakše odgonetnuo

\footnotetext{
${ }^{10}$ Zaklada Marija De Mattias, projekti. Dostupno na: www.klanjateljice.hr/zaklada (22. 10. 2018.)

${ }^{11}$ Usp. Z. LEUTAR, Bibliodrama in Social Work, PPT prezentacija na Sveučilištu Newman, Kansas, SAD, 2017.

${ }^{12}$ Usp. J. L. MORENO, Gruppenpsychotherapie und Psychodrama, 34.

${ }^{13}$ Usp. Z. LEUTAR, H. KRELLER, Primjena bibliodrame u socijalnom radu sa starijim ljudima, u: Revija za socijalnu politiku 21(2014.)2, 219-233.

${ }^{14}$ Usp. isto, 219.
} 
vlastiti problem i vlastite strahove. Nadalje ona pomaže pri suočavanju s raznim situacijama koje u čovjeku izazivaju različite osjećaje, kao i pri suočavanju s vlastitom istinom i postojanjem. ${ }^{15}$ Danas se bibliodrama pokazala kao potrebna u različitim djelatnostima, osobito u strukama vezanim za rad s ljudima (tzv. pomagačkim profesijama). Bibliodrama se primjenjuje u grupnom radu i, iako nije psihoterapija, sadrži određene terapijske elemente. Ona se primjenjuje u pastoralnoj teologiji u radu s različitim skupinama ljudi. Može se primjenjivati u radu s profesionalcima, kao tehnika osnaživanja, ali i u radu s ljudima kojima je potrebna pomoć i podrška. Također se primjenjuje u socijalizaciji, prihvaćanju, pomicanju granica, pristupu bez straha od osude i tuđih razmišljanja. Nadalje pomaže pojedincu da ostane autentičan, da se bez straha poistovjeti s biblijskim tekstom i nađe rješenje koje će ga životno osnažiti i obogatiti. ${ }^{16}$ Danas se od pastoralnih djelatnika zahtijeva veća sposobnost komuniciranja, priopćavanja i dijeljenja vlastitih iskustava, dok je prije bila važna osobna pobožnost. Osim toga u pastoralnoj praksi sve više dolazi do izražaja konkretan čovjek sa svojom poviješću, svojim iskustvom i svojim kontekstom u kojem živi. Polazište je njegovo razmišljanje, osjećanje, vjerovanje ili nevjerovanje i njegovo djelovanje. Bitan je odnos sa samim sobom, drugim pojedincima i skupinama. Sve se više pozornosti pridaje odnosu pojedinca i zajednice. ${ }^{17}$ Obrazovanje svakoga pastoralnoga djelatnika odvija se na četirima razinama. Obuhvaća djelovanje, učenje, život i vjeru. Te razine međusobno se isprepliću i utječu jedna na drugu i niti jednu se ne smije zanemariti na račun druge. Bibliodrama nam može pomoći kako jednako voditi računa o svim razinama. Bibliodrama omogućava čovjeku susret s Bogom »licem u lice «. Pomaže svakome da pronađe svoju vjeru, stabilnost, sigurnost. Ali vjerovanje je proces s mnogo padova i izazova, a bibliodrama podsjeća na to da je i sumnja u samoga sebe na neki način vjera jer taj pristup pruža nadu i siguran put do željenih odgovora. Trenutak je u kojem osoba promišljajući može dotaknuti najdublji dio sebe i svojega bivanja dok se fizički kreće. ${ }^{18}$ Ako ta značenja stavimo u kontekst oblikovanja vlastite vjere, onda tek dobivamo njihovo pravo značenje. Bibliodrama svojom strukturom svakoga potiče na stupanje $u$ akciju, micanje s mjesta, a rad s bibliodramom može se ponuditi svakom čovjeku koji je spreman raditi na sebi, koji se želi suočiti sa svojim potrebama, koji želi raditi na integraciji svoje osobnosti, koji želi ozdraviti, koji se želi pozabaviti svojom

${ }^{15}$ Usp. A. SINCLAIR, An exercise in the theory of practice: The Hermeneutics of Bibliodrama in the Sinclair classroom, u: Journal of Jewish Education 70(2004.)3, 61-73.

${ }^{16}$ Usp. Z. LEUTAR, H. KRELLER, Primjena bibliodrame u socijalnom radu sa starijim ljudima, 219233.

${ }^{17}$ Usp. V. BADURINA, Bibliodrama u službi navještanja, u: Diacovensia 2(1994.) 1, 167-177.

${ }^{18}$ Usp. Z. LEUTAR, I. LEUTAR, Primjena bibliodrame u kurikulumu studija socijalnog rada, u: Socijalne teme 4(2017.), 9-28. 
vjerom odnosno nevjerom..$^{19}$ Bibliodrama je rekonstrukcija biblijskih priča u malim skupinama sudionika koji su zainteresirani za razumijevanje biblijske tradicije. To je razigrani, duhovni i dramatični pristup biblijskom tekstu. Nema životnoga događaja koji nije sadržan u Bibliji. U bibliodramskom procesu obrađen je cijeli raspon ljudskih životnih iskustava kroz čitanja i donošenja biblijskih tekstova: krize u obiteljima i među braćom i sestrama; radosti i problemi komunikacije između muškaraca i žena, prijatelja i neprijatelja, Boga i ljudi; drevne i suvremene dvojbe poput pravde i nepravde, oslobođenja, izgnanstva, ljubavi i izdaje, rođenja i smrti. ${ }^{20}$ Bibliodramske radionice ne provode se kao način da se ljudi uvjere u istinu određene vjere. Bibliodrama, naprotiv, govori onima unutar i izvan tradicije, unutar i izvan zajedničkoga života. Ona je i za Židove i kršćane i agnostike, jednostavno za sve one koji traže smisao života. ${ }^{21}$

\section{Integrativni pristup biblijskomu tekstu}

Međutim bibliodrama ne potječe samo od psihodrame. Kaže se da bibliodrama ima neku vrstu inkorporativnoga karaktera jer se koristi biblijskim tekstovima, uključujući i biblioterapiju i umjetničku terapiju. Bibliodrama je također pod utjecajem psihologije, koja se bavi ljudskim umom. No bibliodrama ima mnogo dublje korijene u kršćanskoj tradiciji, čitanju i razmatranju biblijskih tekstova, gdje se to duhovno čitanje naziva lectio divina, dok se u židovskoj tradiciji interpretacija biblije naziva midrash. Osim toga bibliodrama usredotočuje se na dramske metode kao što su psihodrama i kazališna terapija. Jer drama predstavlja ljudski život i nalik je tijeku ljudskoga života.

U bibliodramskom procesu sudionici razgovaraju o svojim osjećajima i ulogama i interpretiraju biblijski tekst na temelju vlastitoga iskustva. Takav pristup koristi se tehnikama psihodrame te razmatra Bibliju u relacijama osobnoga iskustva iz vlastitoga života. Ipak, bibliodrama se razlikuje od teologije ili biblijske hermeneutike. Bibilodrama uključuje put interpretacije. Svakako najprije treba pročitati biblijski tekst i interpretirati njegovo značenje s pomoću teološkoga, historijskoga, literarnoga, objektivnoga i znanstvenoga pristupa te ga zatim protumačiti na osoban način. ${ }^{22}$ Tako će riječ Božja (biblijski tekst) postati primjenjiva u našem životu i iznova oblikovati životne putove sudionika. Stoga je metoda bibliodrame primjenjiva

${ }^{19}$ Usp. isto, 28.

${ }^{20}$ Usp. Z. LEUTAR, H. KRELLER, Primjena bibliodrame u socijalnom radu sa starijim ljudima, 219233.

${ }^{21}$ Usp. Z. LEUTAR, I. LEUTAR, Primjena bibliodrame u kurikulumu studija socijalnog rada, 9-28.

${ }^{22}$ W. ENGELER, Mehr als ein Spiel Bibliodrama in der Jugendarbeit, u: E. NAURATH, U. POHLPATALONG (ur.), Bibliodrama: Theorie - Praxis - Reflexion, Bonn, 2002., 82-89. 
u područjima socijalnoga rada, obrazovanja i pastoralnoga djelovanja. Potrebno je naglasiti da je za vođenje bibliodrame vrlo važna teološka pozadina i egzegeza pojedinoga biblijskoga teksta već pri samoj pripremi. Stoga se bibliodrama smješta i interpretira u kontekstu kršćanske paradigme.

Bibliodrama uključuje kreativne slike, odnosno skulpture, te vjeru, edukaciju i terapiju s pomoću riječi Božje, odnosno biblijskoga teksta. Takva dinamika donosi kreativnu efikasnost i u drugim kontekstima. Bibliodrama je put produbljivanja imaginacije, kreativnosti, opservacije, sposobnosti, poboljšanja komunikacijskih vještina, fizičke aktivnosti, osvještavanje emocija i senzibilnosti sudionika.

Drugo, sudionici uče kako dopustiti iznošenje mišljenja, kako iznijeti vlastito mišljenje i kako razumjeti druge, s drukčijim mišljenjem te kako uvjeravati, činiti kompromise i kooperativno surađivati.

Treće, sudionici bibliodrame imaju priliku razumjeti druge ljude i naučiti objektivno vrjednovati stajališta drugih, unaprijediti i učiti mudrost zajedničkoga života s pomoću uloga u bibliodrami. Drama je inkorporirana umjetnost. Unutar nje se sudionici mogu prostorno širiti preko golemih područja, uključujući literaturu, povijest, mitologiju, legende, glazbu, umjetnost, ples, kostimografiju, misli, zemljopis, običaje, religiju, kulturu itd.

Bibliodrama ima ulogu grupne psihološke terapije. Ona ne pomaže samo pri razrješavanju grupnih konflikata nego osvjetljava i pomaže rast grupnih interakcija. ${ }^{23}$

U Psalmu 119 kaže se sljedeće: »Tvoja riječ nozi je mojoj svjetiljka / i svjetlo mojoj stazi.« (Ps 119, 105) Stoga je za istraživače zanimljivo kako Bibliju učiniti što efektivnijom i kreativnijom u pastoralnom djelovanju Crkve. Crkva je kroz dugu tradiciju pripremala propovijedi i imamo mnoge biblijske studije o tome, međutim mnogo su rjeđa kreativna iskustva približavanja biblijskomu tekstu. Bibliodrama je metoda susreta s biblijskim spisima na aktivan i participativan način, kroz dramu, radi obrazovanja, izgradnje zajednice ili osobnoga iscjeljivanja. ${ }^{24}$ Nakon analize tih teorijskih pristupa i povijesnoga konteksta čini se opravdanim definirati bibliodramu na sljedeći način: Bibliodrama je metoda grupnoga pristupa biblijskomu tekstu u kojoj se sudionici koriste dramskim kreativnim tehnikama i spontanošću radi individualnoga osvješćivanja i osnaživanja, izgradnje što kvalitetnijih interpersonalnih odnosa i zajedništva s Bogom i jednih s drugima.

${ }^{23}$ Usp. S. BANG, A Study of Church Educational Approach to Bibliodrama in Youth Bible Study, Wachinkton: Wesley Theological Seminary. 2011.

${ }^{24}$ Usp. P. PITZELE, Bibliodrama: A prophetical advertisement, 57-64. 


\section{Struktura bibliodrame}

Pitzele $^{25}$ se bori za pretežno psihodramatski okvir koji se sastoji od zagrijavanja, dijeljenja i integracije. Zagrijavanje se sastoji od dviju faza. Tijekom prve faze facilitator odabire tekst na temelju grupe i njezinih ciljeva. Zatim Pitzele preporučuje da se predstavi dnevni red i popis pitanja za intervju. U drugoj fazi voditelj stavlja likove na scenu, daje upute i iznosi dnevni red. Radnja počinje kada sudionici počinju govoriti kao biblijski likovi, uživljavajući se u igru uloga. Na primjer voditelj može postaviti jednomu od sudionika neko pitanje, a on ili ona će odgovoriti u ime / u ulozi biblijskoga karaktera. Grupni proces dalje se sastoji od sljedećih dijelova: a) uklanjanje uloga: sudionici izlaze iz svojih uloga; b) dijeljenje: sudionici govore o tome kako je bilo igrati određene dijelove (govore samo o sebi kako bi se izbjeglo kritičko govorenje o drugima; c) egzegeza: povezivanje bibliodrame s egezegetskim tekstom; d) savjetovanje s drugim izvorima: povezivanje s tradicionalnim ili suvremenim komentarima i izvorima literature; e) obrada: razgovor o načinu na koji je bibliodrama provedena, estetici, energiji grupe i sl. Struktura Pitzelove bibliodrame ostaje ista bez obzira na to upotrebljava li se za obrazovne ili terapeutske svrhe.

Nasuprot tomu europska bibliodrama ima fleksibilniju strukturu i može uključivati improvizacije, meditacije, tehnike opuštanja, igranje uloga, ples i/ili vježbe kretanja, duboko čitanje i druge tehnike posuđene iz dramske terapije. ${ }^{26} \mathrm{Te}$ se bibliodramske skupine razlikuju ovisno o ciljevima grupe i stručnosti voditelja. Europske bibliodramske skupine uključuju i predstavnike klera, obitelji i opću populaciju. Ovisno o voditelju skupine i o tome gdje se odvija njegov trening te skupine mogu biti ukorijenjene i utemeljene u pojedinim disciplinama kao što su ples, terapija igrom, dramska terapija itd. Bibliodrama se često opisuje kao oblik igranja uloga u kojem su uloge preuzete iz biblijskoga svijeta. Uloge mogu biti one glavnih biblijskih likova poput Adama ili Eve, Marije ili Marte, ili manjih likova poput Seta ili Elizabete. Bibliodrama može pozivati i na igranje uloga likova čija se prisutnost može zaključiti iz maštovitoga čitanja teksta (Noina žena ili majka Šimuna Petra). U bibliodrami rezervoar dostupnih uloga može također uključivati i određene predmete koji se mogu utjeloviti glasom i pokretima (kovčeg u kojem je bio Mojsije na rijeci Nil ili križ na kojem je Isus umro). I mjesta mogu govoriti (rijeka Jordan ili Kalvarija). I životinje mogu progovoriti (zmija u vrtu, pijetao koji je kukuriknuo u zoru). U bibliodrami se mogu izraziti i duhovni likovi (anđeli ili

\footnotetext{
${ }^{25}$ Usp. P. PITZELE, Scripture windows: Toward a practice of bibliodrama, Los Angeles, 1998.

${ }^{26}$ Usp. B. KRONDORFER, Bibliodrama, Dostupno na: 2013. http://faculty.smcm.edu/bhkrondorfer/bibliodrama/ (27. 7. 2017.)
} 
Bog ili Sotona). Bibliodrama nam omogućuje zamisliti i predstaviti cijeli biblijski svemir kao polje maštovite igre. ${ }^{27}$

Kreller $^{28}$ donosi sedam različitih modela bibliodrame i njihove predstavnike:

1. Bibliodrama čije je središte tekst (G. M. Martin) ${ }^{29}$. Ima za cilj vježbanje egzegeze i u središtu su joj višedimenzionalni tekstualni zaključci. Korištene metode jesu tjelesna aktivnost i lingvistika.

2. Bibliodrama u dušobrižništvu (H. Andriessen i N. Derksen $)^{30}$. Cilj toga tipa bibliodrame jest produbljivanje vlastite vjere. $U$ središtu je odnos povezanosti $u$ vjeri, a metoda kojom se koristi jesu razgovori o pitanjima koja se pojavljuju u nekom tekstu.

3. Hagiodrama (Y. Spiegel) ${ }^{31}$. Ima za cilj stvoriti pristup kolektivnoj simbolici kroz tekst. U središtu su religioznost, mitovi, smisao slika u tekstu, a kao metodom koristi se dubinskom psihologijom.

4. Oponašanje (S. Laeuchli) $)^{32}$. Ima za cilj preobrazbu. U središtu su mit, tragedija i kriza. A metode kojima se koriste jesu: konfrontacija, dijalog s publikom (članovima skupine).

5. Psihodramska bibliodrama (H. Heidenreich $)^{33}$. Ima za cilj u kontekstu vlastite biografije razumjeti biblijski tekst i oživjeti ga. U središtu je paralelno biblijska scena i biografska scena. Metoda kojom se koristi jest protagonistički centrirana psihodrama.

6. Bibliodrama kao pastoralno-psihološki rad s Biblijom (W. Drechsel) ${ }^{34}$. Cilj toga modela jest nakon pripovijedanja biblijskoga teksta prepoznati onoga koji pripovijeda i pripovijedanoga. U središtu su tekst, osoba - voditelj. Metoda je psihoanalitičko simboličko razumijevanje.

\footnotetext{
${ }^{27}$ Usp. F. KOHI, Bibliodrama as Therapy within the Church, Quebec, Canada, 2013.

${ }^{28}$ Usp. H. KRELLER, Bibliodrama. Ein Lehr- und Praxisbuch, Erlangen, 2013., 47-48.

${ }^{29}$ Usp. M. G. MARCEL, Sachbuch Bibliodrama. Praxis und Theroie, Stuttgart, 2011.

${ }^{30}$ Usp. H. ANDRIESSEN, N. DERKSEN, Lebendige Glaubensvermittlung im Bibliodrama. Eine Einfuerung, Mainz, 1991.

${ }^{31}$ Usp. Y. SPIEGEL (ur.), Doppel deutlich - Tiefendimension biblischer Texte, Müenchen, 1978.

${ }^{32}$ Usp. S. LAEUCHLI, Die Buehne des Unheils. Das Menschheitsdrama im mythischen Spiel, Stuttgart, 1988.

${ }^{33}$ Usp. H. HEIDENREICH, Eine Auswahl der Vielfalt: Varianten des Bibliodrama in Literatur und Ausbildung, u: Lebendige Seelsorge 46(1995.)3, 156-158.

${ }^{34}$ Usp. W. DRECHSEL, Pastoralpssychologische Bibelarbeit. Ein Verstehens- und Praxismodell gegenwaertiger Bibelerfahrung, Stuttgart, 1994.
} 
7. Procesualna bibliodrama (E. N. Warnes i H. Fallner) ${ }^{35}$. Ima za cilj: utjelovljenje; vizualizaciju; kompresije; Biblije. A u fokusu su odnosi, oblikovanje teksta i prostora, pokreti i susret. Metode: maske, rituali, geste, riječi, rekviziti, aktivnosti tijela.

To su neki od modela koji su prepoznati u literaturi. Struktura je često prilagođena skupini i stoga je u bibliodrami vrlo bitna dinamika same grupe, a za voditelja je vrlo bitno da u fazi zagrijavanja poradi na psihodinamici grupe i da osluškuje samu grupu. Umjesto da se u nastavku teksta teorijski iznosi struktura bibliodrame, poslužit ćemo se osvrtom jedne sudionice $s$ jednoga bibliodramskoga seminara ${ }^{36}$ kako je ona prepoznala te dijelove, a zatim će biti integrirana i interpretacija autorice ovoga članka i voditeljice bibliodrame. Struktura bibliodrame koja je prenesena u Hrvatsku jest sljedeća:

- Upoznavanje i zagrijavanje

- Rad na životnoj strani

- Rad s biblijskim tekstom

- Rad na životnoj strani s pomoću uloga iz biblijskoga teksta i međusobno dijeljenje

- Integracija

\section{Prikaz strukture bibliodrame na temelju iskustvenoga učenja}

U nastavku članka slijedimo osvrt sudionice bibliodrame:

$\gg$ Dan smo započeli s predstavljanjem. Predstavili smo se preko hodograma. Zamislili smo da je u našem krugu karta svijeta i označili mjesto koje predstavlja jug, te se svatko od nas trebao kretati po našemu krugu i reći odakle dolazi i kuda se sve selio kroz život. Prvo se predstavila naša voditeljica, a zatim ostali članovi grupe. Ovaj način predstavljanja mi se činio jako zanimljiv. Malo nas je bilo sram započeti ovo predstavljanje i kada se jedna kolegica otvorila, kasnije je drugima bilo lakše. Bilo je zanimljivo čuti odakle svi dolazimo, gdje smo se selili i na taj sam način dobila neke nove informacije o ljudima koje inače tako dobro i ne poznajem. Dok sam se ja predstavljala bila sam malo sramežljiva, nekako sam se na brzinu predstavila i sjela.«

${ }^{35}$ Usp. E. N. WARNS, H. FALLNER, Bibliodrama als Prozess. Leitung und Beratung, I, Lünburg, 1999.

${ }^{36}$ Bibliodrama je održana na Studijskom centru socijalnog rada Pravnog fakulteta Sveučilišta u Zagrebu u okviru nastave na kolegiju: Duhovnost u socijalnom radu, 2015./2016. akademske godine. 
Ranije smo u tekstu spomenuli važnost psihodinamike grupe. To je upravo bila faza zagrijavanja, u kojoj se sudionici međusobno upoznaju i pri upoznavanju se radi na što kvalitetnijoj psihodinamici grupe. U mjeri u kojoj se sudionici upoznaju i međusobno zbliže, to će kvalitetniji kasnije biti rad tijekom samoga procesa bibliodrame. To je bila jedna od tehnika sociometrije. Mogle su se upotrijebiti još neke vježbe sociometrije, primjerice upitati sudionike koliko iskustva imaju u radu s grupom ili s Biblijom - da se smjeste na skalu od 1 do 10 - a zatim ih upitati zašto stoje upravo na tom određenom mjestu ili slično. Na taj se način stječe otvorenija atmosfera u grupi, a sudionici na neizravan način dobivaju saznanja jedni o drugima. Upravo to sudionica i opisuje:

>Zatim smo se trebali poredati u niz više puta prema različitim karakteristikama. Najprije smo se trebali poredati po starosti i ja sam bila najstarija, pa mi je bilo malo i neugodno, ne znam ni ja zašto, a zatim smo se poredale prema tome koliko imamo braće i sestara - uslijedio je žamor dok se nismo uspjele poredati, zapitkivali smo jedni druge koliko imamo braće i sestara, zatim je uslijedilo nizanje prema tome koliko imamo iskustava s Biblijom, $\mathrm{s}$ bibliodramom. Većina nas nema iskustva $\mathrm{s}$ bibliodramom i ovo nam je prvi put da smo se susreli s tom metodom. Na ovaj način smo se još bolje upoznali i dobra atmosfera je vladala grupom. Nakon ovoga smo ponovno sjeli u krug i svatko od nas mogao je reći kako se osjeća - $\mathrm{i}$ inače smo nakon svake aktivnosti to radili, opisivali smo kako se osjećamo i kako smo se snašli u pojedinoj aktivnosti, mi smo to zvali runda.«

Vrlo je bitno međusobno dijeljenje nakon svake aktivnosti - kako su se sudionici osjećali tijekom pojedine aktivnosti. Isto je tako bitno naglasiti da su sudionici slobodni podijeliti ili ne podijeliti svoje osjećaje. Potrebna je maksimalna tolerantnost. Ako se sudionik ne osjeća spremnim iznijeti svoje iskustvo, na vrlo diskretan način daje se znak da može ići sljedeći sudionik.

»Nakon aktivnosti za upoznavanje u ruke su nam došle Biblije. Hodali smo po dvorani s Biblijom u rukama. U pozadini je svirala glazba, bila je to duhovna glazba, onako cijela umirujuća, nije to bila glazba koja ometa moje misli, već zapravo glazba koja me potiče na razmišljanje. Dok smo tako hodali, razmišljali smo o svom odnosu prema Bibliji, o svom prvom susretu s Biblijom, o posljednjem susretu, o tome koliko nam je često pri ruci, o svojim osjećajima prema Bibliji. Svatko je trebao smisliti riječ kojom opisuje svoj odnos prema Bibliji i izreći je naglas. Nakon toga smo se podijelili u manje grupe, u mojoj grupi nas je bilo četvoro, trebali smo razgovarati o riječi kojom smo opisali svoj odnos prema Bibliji i općenito svom prvom susretu s Biblijom, te smo trebali zajednički napraviti jednu sliku koja će najbolje opisati naš odnos prema Bibliji. Moja riječ je bila poštovanje i strah Božji. Tako bih ja opisala svoj odnos prema Bibliji jer Bog sve vidi i čuje i što god ja rekla 
ili učinila Bog će me u skladu s učinjenim i rečenim nagraditi ili kazniti. Dakako da to nije jedina riječ niti jedini osjećaj kojim mogu opisati svoj odnos prema Bibliji, tu je i ljubav, utjeha u Božjoj riječi i u molitvi, ali nekako je ovaj osjećaj poštovanja i straha Božjeg dominantan. Nekako se u jednu ruku osjećam dobro zbog toga jer strah Božji je i jedan od darova Duha Svetoga, smatram da je to dar za svakoga tko ga posjeduje jer tako imamo više osjećaja jedni za druge i samim tim je lakši suživot ljudi jednih s drugima. A u drugu ruku nekako mi je žao što je taj osjećaj dominantan, jer odnos prema Bogu kao prema ocu ne bi trebao uključivati samo poštovanje već i neku dublju povezanost i ove osjećaje koje sam gore nabrojila koji su kod mene sekundarni u odnosu na osjećaj poštovanja i straha Božjeg. Nakon što smo u grupi raspravili tko ima kakav odnos prema Bibliji, trebali smo osmisliti sliku kojom prezentiramo svoj odnos prema Bibliji. Mi smo to osmislile na način da jedna sklopi ruke i predstavlja molitvu, druga ima otvorenu Bibliju i čita što predstavlja utjehu u Božjoj riječi, treća je držala Bibliju na srcu i predstavljala je ljubav, a ja sam imala podignute ruke i pogled prema nebu kao znak otvorenosti Božjoj riječi i pronalasku utjehe. Ja sam se malo počela smijati dok sam tako držala ruke, imam taj problem inače da se dosta smijem, a često mi se to događa i kad nije primjereno jer mi misli jednostavno odlutaju, sjetim se nekih smiješnih situacija, a kad se počnem smijati i kad mi je nešto uistinu smiješno teško mi se zaustaviti, kasnije sam taj svoj problem podijelila i s grupom jer mi je često neugodno u tim situacijama. Zezali smo se u grupi da mi je dodijalo držati ruke, pa da sam se zato počela smijati. I druge kolegice su osmislile lijepe slike i svaka slika je bila popraćena pljeskom. Ova aktivnost me je baš ispunila, lijepo smo osmislile sliku i baš sam bila nekako zadovoljna. Nakon ovoga smo opet imale jednu rundu gdje smo pričali kako se osjećamo i ja sam se osjećala zadovoljno, ali mi je bilo i tisuću pitanja u glavi, prvenstveno mi je bilo na pameti koliko ja zapravo živim Božju Riječ. Dosta nas je govorilo kako nismo često u kontaktu s Biblijom i kako bi zapravo htjeli više čitati Bibliju, ali ja sam se više zapitala kako ja to živim, slijedim li Riječ Božju.«

Taj dio aktivnosti odnosio se još uvijek na zagrijavanje i, zapravo, zajedničko promišljanje grupe i svakoga sudionika što im znači Biblija u životu i kakva je njihova poveznica s Biblijom. To pomaže sudionicima da krenu korak dalje u međusobnom upoznavanju, u psihodinamici, a voditelju bibliodrame pomaže da bolje upozna grupu i vidi na kojoj razini može raditi s grupom i u kojem smjeru. Ponovno je na kraju vježbe naglašeno dijeljenje, posvješćivanje kako su se sudionici osjećali tijekom aktivnosti.

»Voditeljica nam je čitala priču o Izgubljenom sinu. Nakon toga smo uzeli papire s pričom i sami smo čitali hodajući. Ponovno smo sjeli u male grupice i dobili tumačenje priče o Izgubljenom sinu, svaka grupica trebala je pročitati određeni dio tumačenja i kasnije ga prezentirati cijeloj grupi. To mi je bilo jako zanimljivo, 
posebno to kako se u tumačenjima svaki detalj priče nastoji proučiti i sve mi je to imalo smisla na jednoj dubljoj razini. Dosad sam često puta čula priču o Izgubljenom sinu, ali više sam je onako površinski razumjela, prije dok sam čitala tu priču u centru je nekako bio mlađi sin kao pokajnik i milosrdni otac, ali zapravo nisam ni obraćala pozornost na drugog izgubljenog sina kako je starijeg sina nazvao pater na misi koju smo slušale drugi dan. Tumačenje mi je uistinu pomoglo da u cijelosti shvatim ovu priču. «

Grupa je radila na biblijskom tekstu o izgubljenom sinu i milosrdnom Ocu (Lk 15, 1-3, 11-32). Sudionica govori o čitanju teksta i zajedničkoj analizi teksta, odnosno o tome da im je bila dostupna i egzegeza toga teksta koji su mogli čitati individualno ili grupno. To je jedan od mogućih načina. No sudionicima se mogao i ranije dati i tekst i egzegeza da na susret dođu pripremljeni, a postoji i inačica u kojoj se namjerno izbjegava egzegetsko tumačenje teksta.

»Nakon toga smo ponovno imali tekst u ruci. Čitali smo ležeći na dekicama. To mi je iskustvo meditacije bilo jako lijepo, onako osjećala sam se skroz smireno, jednostavno sam utonula u svoje misli o izgubljenom sinu. Trebali smo izabrati riječ ili rečenicu koja nam je nekako najznačajnija u priči, te razmišljati o njoj. Ja sam izabrala rečenicu 'bijaše mrtav i oživje'. Meni je ta riječ bila znakovita jer na neki način pokazuje kako čovjek iako je živ može umrijeti, tj. čovjekova duša može umrijeti kad su mu na prvom mjestu vrijednosti koje mu samo kratkoročno mogu donijeti sreću, ali isto tako čovjek može i spoznati svoje grijehe i pokajati se, te na taj način i oživjeti. Nakon meditacije smo ponovno hodali i trebali smo jedno drugome reći koju smo riječ ili rečenicu izabrali. Nekako su mi svi nakon meditacije izgledali veselo i zadovoljno, te svježe u odnosu na početak kada smo došli. Nakon toga smo trebale predstaviti svoju riječ ili rečenicu nekom gestom, time da je to moglo biti u dvorani, ali i vani. Uistinu je bilo zanimljivih riječi i načina predstavljanja. Nakon što smo osmislili gestu za svoju riječ svi članovi grupe su to trebali ponoviti. Ja sam svoju rečenicu predstavila tako da sam rekla 'bijaše mrtav' otvorila bih vrata od dvorane prošla kroz vrata i rekla 'oživje', nakon toga su svi članovi grupe trebali to ponoviti. To mi je baš bilo zanimljivo i hodali smo i van dvorane, po hodniku i van u dvorište. Zanimljivo je koliko smo svi kreativni i na koliko različitih načina poimamo iste stvari. Na ovaj način smo se još više svi upoznali i međusobno povezali u nekim razmišljanjima.«

Bibliodrama poznaje riječi, slike, skulpture, geste kojima se izražava. Sudionici grupe suočavaju se s tekstom najprije na kognitivnoj razini, a nakon toga na emocionalnoj jer silaze dublje u značenje teksta za njihov život. Tako mogu izraziti pojedinu riječ, rečenicu ili odlomak koji ih se osobito dojmio i koji identificiraju s vlastitom stvarnošću. Za čitanje teksta na kognitivnoj razini važna je osvijetljena prostorija, 
a kada se ide na emocionalnu razinu, onda je poželjno da prostor bude što tamniji kako bi sudionici zaronili dublje u tekst. Svatko ima svoju riječ, rečenicu, gestu, sliku, ali zapravo cijela skupina pokušava doživjeti ono što pojedini sudionik doživljava po toj riječi i na taj način produbiti cijeli tekst; sada ga više ne čitaju, nego izgrađuju svoje slike ili skulpture.

»Nakon ovoga ponovno smo hodali po dvorani, razmišljali smo o svojem iskustvu odlaska, povratka, kako smo se osjećali tada. Na ovaj način smo priču o Izgubljenom sinu pokušale pretočiti u stvarni život. Voditeljica nam je davala upute o čemu da vodimo računa, na koje bitne aspekte svog iskustva da se osvrnemo. Ja sam razmišljala o svom prvom odlasku u Zagreb na faks i kako mi se bilo teško rastati od obitelji, posebno od oca s kojim sam jako povezana. To mi je onako bilo jako dirljivo, prisjetila sam se svega kako je to izgledalo, što sam osjećala. Kasnije smo na dekicama ponovno razmišljali o tom iskustvu i svatko od nas je svoju priču iznio voditeljici. To mi je bilo baš lijepo, nekako sam se osjećala lakše kad sam to nekome iznijela. Za kraj smo razgovarali o tome kako se osjećamo. Ja sam se uistinu osjećala zadovoljno i ispunjeno. Došla sam umorna i neispavana, ali tijekom aktivnosti taj umor kao da je nestao.«

Bibliodrama ide uvijek po formuli ŽIVOT - BIBLIJA - ŽIVOT. Sudionici su ovdje bili na strani života i promišljali su o svojim životnim odlascima te se u njih uživljavali kako bi što dublje mogli integrirati svoj život i tekst iz evanđelja. Vrlo je bitno tekst povezati sa životom.

»Ponovo smo radili na riječima koje su se pojavljivale u biblijskom tekstu i u našim životnim pričama. Dodatno smo se zagrijavali za bibliodramu tako da je voditeljica napisala po jednu riječ na četiri papira i postavila ih na četiri strane u dvorani, te se svatko od nas trebao smjestiti kod riječi koja nam je nekako najbliža i to smo radili u tri kruga. Moje riječi su bile otac, radost i spoznaja. Nakon toga smo u grupi razgovarali o tim riječima, zašto smo ih izabrali i kako su te tri riječi povezane i kako su s nama povezane. $\ll$

Bila je to još jedna od tehnika u kojoj su sudionici sudjelovali kako bi uistinu imali priliku međusobno dijeliti ono što osjećaju i gdje se pronalaze. Jasno, moguće je upotrijebiti i mnoge druge tehnike radi integracije osobnosti i biblijskoga teksta. Riječi za četiri kuta voditelj kreira na temelju onoga što čuje u samoj skupini, što im je bitno i važno i što će sudionicima koristiti da si osvijeste nešto vezano uz njihovu osobnost i biblijski tekst. Ujedno je to i prilika da oni jedni drugima verbaliziraju zašto su nakon šetnje po dvorani stali upravo kod neke određene riječi i kako je ta riječ povezana s njihovim životom. Nakon toga pokušaju integrirati sve tri riječi koje su izabrali i dati im vlastiti smisao. 
»Trebali smo odglumiti priču o Izgubljenom sinu. Najprije smo odabrali uloge, to su bile i žive i nežive stvari. Tako smo imali oca, majku, starijeg i mlađeg sina, slugu, životinje, Nebo, sunce, kamen, mladost, sreću, odluku, imanje. Bilo je uistinu zanimljivo, nije bilo puno pripreme, samo smo se na brzinu preobukli i pripremili ostale rekvizite što su nam trebali. Nismo se dogovarali tko će što reći, kako će iznijeti svoju ulogu, sve je bilo nekako spontano. Ja sam bila stariji sin i nastojala sam se što više uživjeti u ulogu. Smatram da sam na kraju i uspjela, cijelo sam vrijeme nastojala pokazati da me nije briga gdje je moj brat i ocu sam govorila da ne misli na njega, da se ne brine, da ni brata nije bilo briga za nas kad je otišao. Bilo je i trenutaka smijeha, ali brzo bih nastavila dalje, nije mi se dogodilo da sam puknula od smijeha i da se nisam mogla zaustaviti što se inače zna dogoditi, tako da mi je jako drago da sam se uspjela kontrolirati. I bilo je zanimljivo kako će završiti priča sa starijim bratom, hoće li se on na kraju pridružiti slavlju ili ne. Ja sam na kraju kao stariji brat odabrala sretan završetak, bacila se u zagrljaj svome bratu i onda smo svi skupa proslavili njegov povratak. Meni se jako svidjelo kako smo mi to odglumile posebno zato što je sve to ispalo spontano, svi smo se uspjeli uživjeti i bez nekog posebnog dogovaranja. Ja sam se uspjela uživjeti u ulogu starijeg brata jer sam to povezala i sa svojom obitelji, moj djed ima većinom žensku unučad pa na moga brata kao muško gleda posebno, onda mu se mi često onako iz zezancije tužimo da mu je moj brat najdraži. Tako se i stariji sin ponaša i misli da ga otac ne voli jer mu nikad nije dao jare da se $s$ prijateljima proveseli. Nakon glume smo razgovarali u grupi o pojedinim ulogama, kako se tko osjećao u svojoj ulozi, te koje bi tri glavne karakteristike dao svom liku. Ja sam starijem bratu pridružila karakteristike: ljutnju, ljubomoru i ljubav. Ljutnju jer je u početku bio ljut na brata što je otišao, kasnije i na oca. Zatim mi se činio i ljubomoran zato što je otac pripremio slavlje za njegovog brata i što mu je stalno bio u mislima dok ga nije bilo, ali na kraju, kako smo mi u bibliodrami odredili da se i stariji brat pridružuje slavlju, na kraju prevladava ljubav prema bratu nad ljutnjom i ljubomorom. Ja sam se baš osjećala sretno, imale smo pauzu, pa smo i na pauzi dosta o tome razgovarale, kako je tko iznio svoju ulogu. Meni se posebno svidjela kolegica koja je glumila mlađeg brata, ona se uistinu uživjela i po mom mišljenju vrlo dobro odglumila.«

Ovdje imamo opis igre. Sudionica je u svom opisu bibliodrame izostavila važno područje, a to je uživljavanje u uloge. Voditelj bibliodrame vodi sudionike kroz glavne uloge u tekstu da bi se pokušali uživjeti i prepoznati u kojoj se ulozi doista najbolje osjećaju i prepoznaju. Tako se u ovome tekstu radilo na uživljavanju u ulogu oca, starijega sina i mlađega sina. A nakon svake odigrane uloge vrlo je bitno da osoba iziđe iz prethodne uloge i bude ona koja jest. Sudionici zatim biraju uloge koje žele. Kako smo ranije u uvodnom tekstu ovoga članka napomenuli, te uloge mogu biti i žive i nežive prirode, to mogu biti i osjećaji. Najvažnije je to da sudionik izabere 
ulogu s kojom se uistinu identificira. Nakon izbora uloge potrebno je predstaviti se uživljavajući se u ulogu i onda, kako i sudionica navodi, igru započeti spontano. U igri je vrlo bitna spontanost i kreativnost, da sudionici izvode tekst onako kako ga osjećaju, a ne onako kako je navedeno u Bibliji. Tako tijekom igranja uloga dolazi do osvješćivanja vlastite stvarnosti i životnih priča svojstvenih protagonistima. Igra završava na znak voditelja. Vrlo je važno da grupa nema predviđenih aktivnosti, nego da u spontanosti njihovo nesvjesno iziđe na scenu. Nakon toga, u grupnom dijeljenju, pojedinci i grupa mnogo toga opet osvijeste kroz samu igru.

$\gg$ Nakon toga smo trebale nešto nacrtati ili izraditi neku figuricu kojom bismo opisale ono što smo doživjele u ova dva dana, te smo svoje radove izložile na ploču. Najprije smo pogađale što svaki uradak može značiti, a onda je svaki autor trebao reći jesmo li pogodile i objasniti što je htio reći svojim crtežom. Moja je zamisao bila da pokažem svima da je Bog svuda oko nas i da nam svoju ljubav pokazuje na različite načine, tako sam nacrtala jedan crtež na kojem sam prikazala sunce, oblake, stablo, livadu, ljude, zemlju i sve je to bilo u obliku srca. Oblak, sunce u obliku srca, srce u ljudima i između ljudi, zemlja u kojoj izraste krumpir koji isto ima oblik srca, list koji pada sa stabla i također ima oblik srca. Moja poruka je bila - Bog je svuda oko nas, samo ga treba slijediti. Svi su radovi uistinu bili lijepi i imali su svoju poruku, te su oni pružili još jedan dokaz kako zadovoljni i ispunjeni odlazimo s bibliodrame.«

To je bio treći i posljednji dio u bibliodrami, integracija. Trebalo je s pomoću određenoga kreativnoga izraza - bilo crteža, simbola ili slično - izraziti sve ono što se događalo kroz cijeli tijek bibliodrame, od samoga početka i zagrijavanja, dijeljenja, teksta, životne strane, uloga i igre. Potrebno je da sudionici na kraju integriraju intrapersonalne i interpersonalne odnose i na taj se način izraze. ${ }^{37}$

\section{Zaključno razmatranje}

Bibliodrama je metoda u pastoralnom radu u kojoj sudionici donose vlastita životna iskustva, osobnost, povijest i kulturu, susreću se s biblijskim tekstom te ga integriraju u vlastitu stvarnost. Bit bibliodrame jest suočavanje s biblijskim tekstom i pojedinim ulogama. Zahvaljujući aktivnom pristupu, sudionici imaju priliku na drugi način sagledati sebe, vlastiti svijet, kao i svijet koji ih okružuje. Za voditelja bibliodrame bitno je poznavati psihodinamiku grupe. Metoda bibliodrame može biti korisna metoda za same pastoralne djelatnike u smislu vlastitoga rada na sebi kako bi bili kvalitetnije osobe i time i profesionalci, da rade na vlastitom samopoimanju i prihvaćanju što im pomaže da budu bolji i na profesionalnome planu. Osim

${ }^{37}$ Detaljnije informacije o strukturi ovdje prikazane bibliodrame moguće su u: H. KRELLER, Bibliodrama. Ein Lehr- und Praxisbuch, Erlangen, 2013. 
navedenoga može se njome koristiti kao grupnom metodom s različitim skupinama korisnika. Bibliodrama je zahvalna stoga što njome može koristiti u različitim skupinama te u različitim prostorima. Zahvaljujući i terapeutskim elementima koje bibliodrama ima u sebi, vrlo je zahvalna i za sudionike koji prolaze različite životne izazove. Kao kreativna metoda izvrsno je sredstvo kojim se osobe mogu izraziti posredno te na taj način ostati zaštićene. Nadalje je Biblija prepuna likova, gdje se svatko može pronaći. Biblija nam ne nudi samo likove s kojima ćemo se poistovjetiti već nam daje i toliko tražene odgovore na egzistencijalna pitanja koja si čovjek današnjice postavlja. U radu se htjelo pokazati kako je bibliodrama metoda koja kod nas, u Hrvatskoj, nije dovoljno prepoznata kao sredstvo rada i kako sve više ulazi u neke pomagačke struke, kao i u pastoralno djelovanje. U kombinaciji s individualnim pastoralnim radom grupna bibliodrama može pružiti dobre rezultate pri radu s različitim skupinama te im pomoći da savladaju poteškoće koje imaju.

Biliodrama se može primjenjivati u svim dobnim skupinama: od predškolske dobi do treće životne dobi.

U pastoralnom radu bibliodrama se može primjenjivati radi jačanja grupne kohezije za različite zajednice: ministrante, sjemeništarce, bogoslove, redovničke zajednice, pastoralna vijeća, ostale zajednice unutar župe, vjeroučitelje, svećenike dekanata... Jednako kao radi podrške roditeljima djece s teškoćama u razvoju, osobama s invaliditetom i slično.

Pastoralni izazov bibliodrame očituje se susretom s Riječju Božjom na nov, spontan i kreativan način koji postaje djelotvoran na trima razinama: ${ }^{38}$

- rad na sebi

- kvalitetniji interpersonalni odnosi

- stjecanje novih znanja i vještina.

Rad na sebi uključuje:

- dublje promišljanje i doticaj sa samim sobom

- motivaciju životnih izbora i preispitivanje ispravnosti odluke

- važnost vjere u životu

- upoznavanje mehanizama osnaživanja u svakodnevnici življenja

- osvješćivanje vlastitih vrijednosti

- osvješćivanje vlastitih jakih i slabih strana

- osvješćivanje vlastitoga smisla života

${ }^{38}$ Usp. Z. LEUTAR, I. LEUTAR, Primjena bibliodrame u kurikulumu studija socijalnog rada, 25-28. 
- osvješćivanje vlastitih stavova, osjećaja i mišljenja

- osvješćivanje vlastitih stereotipa.

Kvaliteta interpersonalnih odnosa u bibliodrami:

- osjećaj zajedništva i međusobno bolje upoznavanje

- rad na boljim medusobnim odnosima

- bolji suradnički odnos

- bolje razumijevanje sebe i drugih

- poštovanje i prihvaćanje različitosti

- učenje od drugih.

Stjecanje znanja i vještina:

- znanja i spoznaje o važnosti duhovne dimenzije čovjeka

- znanja o važnosti psihodinamike grupe

- vještine grupnoga vođenja

- razvijanje kreativnosti u radu

- razvijanje komunikacijskih vještina

- sudjelovanje u timskom radu

- znanja o grupnom radu

- znanja o mehanizmima nošenja sa stresovima i krizama. 


\section{BIBLIODRAMA AS A PASTORAL CHALLENGE}

\section{Zdravka LEUTAR*}

Summary: The introductory part of the paper presents a historical account of the origins of Bibliodrama. Bibliodrama is a method of group approach to the biblical text where participants use creative techniques of drama and spontaneity to ensure individual awareness and empowerment, to build better interpersonal relationships and communion with God and with one another. There is no life situation for which a suitable life experience could not be found in the Bible. Participants of Bibliodrama apply their life experience to the biblical text and deepen it by deeply integrating their own lives and awakening their own reality, thus being strengthened. The paper theoretically analyses various approaches to Bibliodrama, particularly European and American. It also elaborates seven types of Bibliodrama and their representatives. In Croatia, Bibliodrama has been applied in pastoral work and assisting professions since 2013. Bibliodrama was introduced in Croatia from Germany, the type derived from psychodrama. Its structure is as follows: Introduction and $\gg$ warm up «; Working on the $\gg$ life side $\ll ;$ Working with biblical texts; Working on the $>$ life side $<$ through the roles from the biblical text; Integration. The paper analyses the elements of the above structure through a presentation of one participant's activities in Bibliodrama and explanation of individual elements. It is very important that the leader of Bibliodrama understands the group psychodynamics which can be of great help in improving the performance of Bibliodrama and can cause resistance and regression of participants. Bibliodrama is used in pastoral work with all age groups, but it is most commonly used in groups with young people and children. Bibliodrama can also be applied in different groups within the parish community in order to achieve the highest quality of group cohesion and companionship. It can also be applied to build up pastoral workers and for self-improvement. The essential dimension of Bibliodrama is that it involves the whole person at all four levels: cognitive, emotional, spiritual and social.

Keywords: Bibliodrama, pastoral work, self-improvement, interpersonal relationships, companionship.

\footnotetext{
* Full Prof. Zdravka Leutar, Ph. D., University of Zagreb, Faculty of Law, Department of Social Work, Nazorova 51, 10000 Zagreb, Croatia, zdravka.leutar@pravo.hr
} 